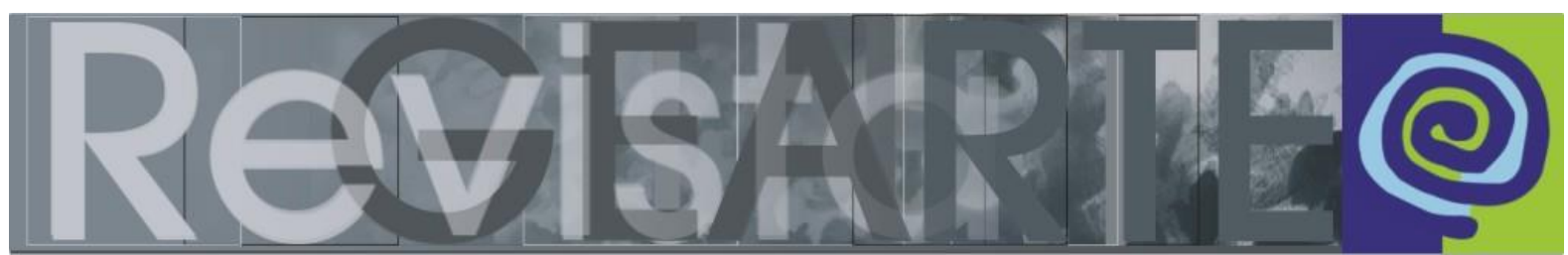

ISSN 2357-9854 | e-ISSN 2596-3198 (online)

\title{
Práticas que convidam a olhar e a pensar relações e sentidos construídos pela criança em sua experiência de desenhar na educação infantil
}

\author{
Daniele Marques Vieira \\ (Universidade Federal do Paraná — UFPR, Curitiba/PR, Brasil) \\ Silvia Pandini \\ (Universidade Federal do Paraná — UFPR, Curitiba/PR, Brasil)
}

\begin{abstract}
RESUMO - Práticas que convidam a olhar e a pensar relações e sentidos construídos pela criança em sua experiência de desenhar na educação infantil - Este artigo apresenta relações que se inspiram em Derrida (2002) para pensar a prática do desenho e a constituição da experiência de desenhar pela criança, tendo como foco situações educativas na educação infantil, com crianças entre 20 meses e 36 meses. Propõe as narrativas visuais (COUTINHO, 2010; VIEIRA, 2016) como metodologia para apresentar elementos que compõem as situações educativas em foco, e partir das dimensões da filosofia e da estética (BENJAMIN, 1986; DERRIDA, 2002; BACHELARD, 2008; 2013), analisa os aspectos implicados nas práticas (RICHTER, 2016) a fim de compreender a constituição da experiência infantil. E ainda, delineia elementos estruturadores das práticas "Contexto de Grafismo" e "Contexto de Observação ao Ar Livre" pela evidência de uma didática pertinente ao que postulam as DCNEI, e por apresentar referentes da cultura plástica e propiciar a emersão de conteúdos subjetivos representados pelo imaginário infantil, configurando uma inter-relação de Campos de Experiências.
\end{abstract}

PALAVRAS-CHAVE

Práticas. Experiência de Desenhar. Educação Infantil.

RESUMEN - Prácticas que invitan a mirar y pensar acerca de las relaciones y significados construidos por el niño en su experiencia de dibujar en la educación infantil - Este artículo presenta un ensayo que se inspira en Derrida (2002) para pensar la práctica del dibujo y la constitución de la experiencia de dibujar por el niño, teniendo como foco situaciones educativas en la educación infantil, con niños entre 20 meses y 36 meses. Propone las narrativas visuales (COUTINHO, 2010; VIEIRA, 2016) como metodología para presentar elementos que componen las situaciones educativas en foco, y partir de las dimensiones de la filosofía y de la estética (BENJAMIN, 1986; DERRIDA, 2002; BACHELARD, 2008; 2013), analiza los aspectos implicados en las prácticas (RICHTER, 2016) a fin de comprender la constitución de la experiencia infantil. Y además, delinea elementos estructuradores de las prácticas "Contexto de Grafismo" y "Contexto de Observación al Aire Libre" por la evidencia de una didáctica pertinente a lo que postulan las DCNEI, y por presentar referentes de la cultura plástica y propiciar la emersión de contenidos subjetivos representados por el " imaginario infantil, configurando una interrelación de Campos de Experiencias.

PALABRAS CLAVE

Prácticas. Experiencia de Dibujar. Educación Infantil.

\section{Para pensar relações educativas implicadas na experiência de desenhar}

Este texto, propõe pensar o desenho como acontecimento, prática que possibilita à criança desenvolver o olhar e o pensar sobre o mundo, sob a inspiração 


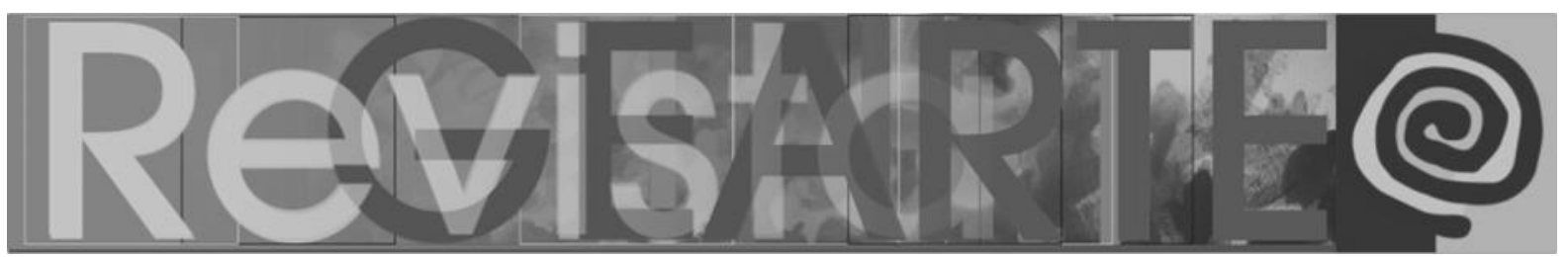

de Derrida (2002) como aquilo que não se vê vir, mas, que surpreende por um efeito inesperado. E por que não dizer, assombra o sujeito-criança em sua capacidade de deixar marcas - traços, riscos e rabiscos (RICHTER, 2016) -, pela iminência do imaginário e suas decorrências na interpretação do vivido, enredando relações que constroem sentidos próprios à perspectiva infantil.

Em Pensar em não ver (2002), Derrida destaca o desenhista como alguém que vê vir aquilo que almeja representar, quando vislumbra o traço movido pela intencionalidade artística. No entanto, no momento em que traça e deixa marcas, esse movimento em que o desenho inventa e pelo qual o sujeito se inventa, "o desenhista é de algum modo cego, em que ele não vê, ele não vê vir, ele é surpreendido pelo próprio traço que ele trilha" (DERRIDA, 2002, p.71). Aqui, propomos pensar a criança na construção da experiência de desenhar - do grafismo ${ }^{1}$ ao desenho -, desde as primeiras ações com riscantes, quando as marcas que imprime no papel são tidas como acontecimento à sua potência de transformar o pensamento em algo concreto, daquilo que o imaginário alimenta a sua subjetividade e que a palavra nomina e define, ao mesmo tempo em que se pronuncia o gesto. Nesse sentido, pensamos com Richter (2016) o necessário intuito fenomenológico ao olhar para os primeiros traços das crianças pequenas como uma "abertura à surpresa que emerge do interesse pela experiência de traçar linhas" (RICHTER, 2016, p. 202), são ensaios que constituem o próprio processo de agir com determinada materialidade à produção de efeitos, pelo gesto e ímpeto de realização.

Riscar e rabiscar dizem respeito à experiência lúdica de tornar visível a ação do corpo traçar linhas que não delimitam objetos ou figuras, mas propõem e instauram percursos que se inscrevem no tempo: uma linha renuncia; uma linha repousa ao se deter. Uma linha fecha; outra linha arredonda; outra alonga o olhar. (RICHTER, 2016, p. 203)

1 Compreende-se o grafismo como um conjunto de traços, rabiscos, marcas, os quais constituem as primeiras impressões realizadas pela criança no seu intento de produzir efeitos e concretizar o simbólico em algo visível a partir de materialidades com propriedades permanentes. 


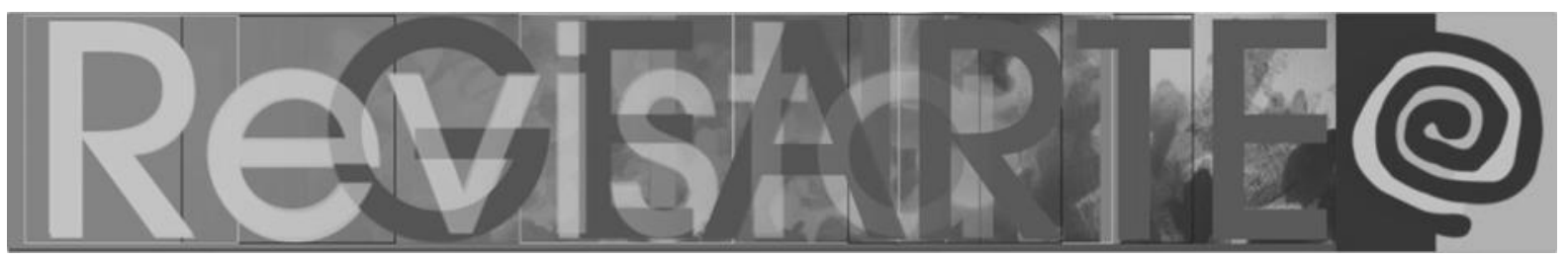

Esse fazer que pode ser repetido tantas vezes, com o sentido de recomeçar ou de alcançar de novo o sentimento de realização, realimenta e promove maior elaboração do gesto, tal como a busca de algo que o imaginário infantil persegue, o que remete ao conceito benjaminiano de experiência referindo recriação como um "fazer sempre de novo" (BENJAMIN, 1986, p 253). Nessa perspectiva, esse começar sempre de novo retém um sentido de transformar o gesto em hábito, valendo-se da repetição como oportunidade ao aprofundamento e alargamento dos conteúdos vivenciais que perpassam esse modo de fazer, o que também podemos chamar de brincadeira e constitui a própria experiência da criança.

Tendo em vista a possibilidade da prática promover situações educativas que convidem a criança pequena ao fazer de novo como oportunidade à construção de sua experiência, nos indagamos: como a vivência do grafismo enquanto possibilidade à exploração e experimentação de materialidades e à produção de marcas e pulsão do imaginário, pode constituir uma estrutura de oportunidade para a construção da experiência do desenho pela criança? O imaginário, presente no ato de desenhar, como pensamento de "chamar a vir" (DERRIDA, 2002), seria o que nutre a criança experiência?

Com essas questões, nos lançamos a pensar a construção pela criança da experiência de desenhar - do grafismo ao desenho - na educação infantil, como ato de imprimir marcas, produzir significados, expressar-se, utilizando narrativas visuais como metodologia de captura de elementos estruturadores dos momentos que compõem a situação educativa em evidência, cujas ações da criança em suas interações com a materialidade proposta e seus pares, são reveladoras de um modo peculiar à construção da experiência infantil.

Vale destacar que as narrativas visuais, produzidas a partir de imagens selecionadas nesta investigação, se compõem por uma relação constituída entre observador e observado assentada no diálogo que pretende "apreender as crianças e as suas ações de modo inteiro e particular" (COUTINHO, 2016, p. 75). Nesse âmbito, 


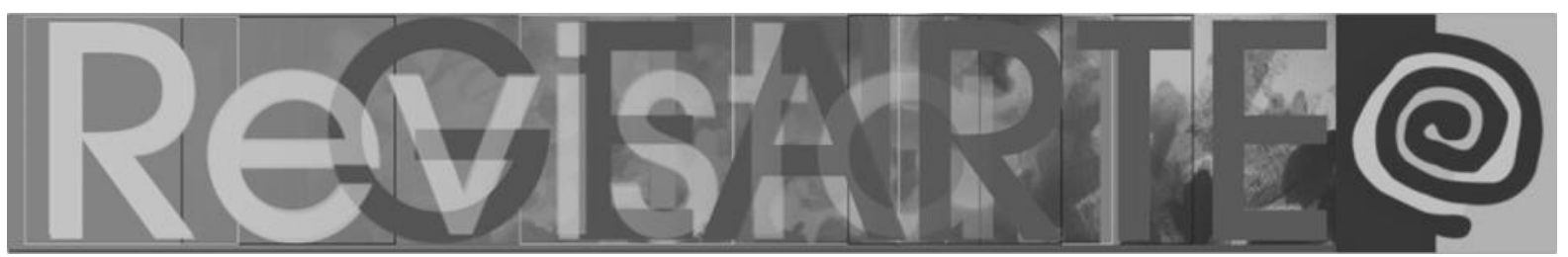

podemos situar o adulto observador e produtor de imagens pelo ato de fotografar, como uma presença também percebida pela criança que, aos poucos é aceita como parte do contexto, conforme a própria ação da criança possa fluir de forma autônoma. Ao mesmo tempo em que este sujeito-observador-fotógrafo captura o instante do momento em questão, está imerso na atmosfera que envolve a todos, sendo também influenciado pelos movimentos, palavras e diálogos que preenchem de significados as ações das crianças, o que necessariamente impactará em sua interpretação (VIEIRA, 2016).

Nessa perspectiva, a dimensão da filosofia, da visibilidade como possibilidade essencial de ver o que não é visível, demarcada por uma relação com o pensamento, constitui campo de aproximação ao imaginário infantil; e a dimensão da estética, cujo traço infantil se veste de novidade e imprevisibilidade por reter o efêmero, evidenciada em um efeito impresso no papel sob significados intrínsecos ao ato de deixar marcas e desenhar, vincula a criança à sua produção e delineia seu ponto de vista. Assim é que as narrativas visuais se mostram pertinentes à análise de situações que envolvem a experiência de desenhar - do grafismo ao desenho - na educação infantil, compreendida a imagem fotográfica como aparato de observação (VIEIRA, 2016), o que permite olhar, perscrutar, relacionar e interpretar seus elementos por uma atitude que lança mão da própria experiência, acionada por aquilo que se compõem à imagem como índice de dada realidade, e com ela estabelece relações. Contudo, se denota que isso que é acionado no sujeito-observador não está visível na imagem, mas decorre daquilo que seus referentes dão a pensar, pois "seja o que for que ela dê a ver e qualquer que seja a sua maneira, uma foto é sempre invisível: não é ela que nós vemos" (BARTHES, 1980, p. 20). O invisível, um algo que não se pode ver, remete à ideia de um vazio que urge ser preenchido por significados cuja composição da imagem, com seus elementos-índice, aciona referentes no observador e constrói a reflexividade da experiência educativa (VIEIRA, 2016).

Portanto, sob o entendimento de pensar relações educativas implicadas pela experiência, este ensaio pretende evocar a reflexão acerca do sentido educativo de 


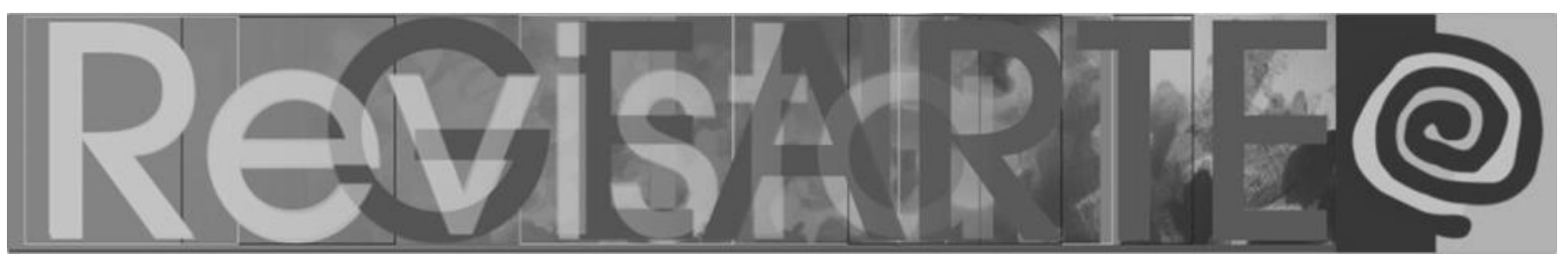

práticas que pretendem promover junto às crianças a experiência de desenhar na educação infantil, evidenciando elementos didáticos que lhes permitem pensar em não ver para apenas deixar chegar o pensamento que chama sua interioridade, o imaginário infantil, este, constituinte de sua experiência a revelar-se em gestos, intenção e produção criativa.

Nesse âmbito, podemos pensar e compreender o desenho em sua complexidade, como expressão e capacidade a ser desenvolvida. Mas, também considerar que na educação infantil, apresentar materialidades pertinentes à faixa etária, consiste dentre os saberes da prática, daqueles que merece reflexão. Sobretudo, no momento atual quando a discussão sobre os campos de experiência (OLIVEIRA, 2018), estruturadores do currículo dessa etapa da educação básica, têm nos provocado a pensar o sentido educativo das propostas que apresentamos às crianças, e sua relação com o que efetivamente elas constroem em suas vivências na instituição educativa como a própria experiência. Concordando com o que aponta Oliveira (2018), consideramos que à compreensão do que consiste campo de experiência, como um novo paradigma à prática educativa dessa etapa, postulada pelas Diretrizes Curriculares Nacionais para a Educação Infantil (BRASIL, 2009), envolve dois aspectos intrínsecos à sua concepção: 1. a criança é o centro da proposta pedagógica - sujeito de direitos que a cada momento da vida detém uma condição determinante ao processo educativo; 2. a experiência se constrói das relações que o sujeito-criança estabelece em suas interações no mundo - com os outros sujeitos e os elementos físicos-materiais do seu entorno - e consigo por aquilo que advém do vivido - sua trajetória de conquistas e saberes construídos.

Assim, nos propomos a analisar situações educativas ${ }^{2}$ representadas por narrativas visuais produzidas a partir de momentos planejados com crianças de idades

2 As situações educativas representadas neste ensaio, advém da prática cotidiana de uma instituição de educação infantil privada, localizada no município de Curitiba, Paraná, cuja proposta se estrutura pelo diálogo com perspectivas pedagógicas alicerçadas na escuta, nas relações e nas linguagens da criança, sob condições e por meio de estratégias da prática que colocam as crianças em contato 


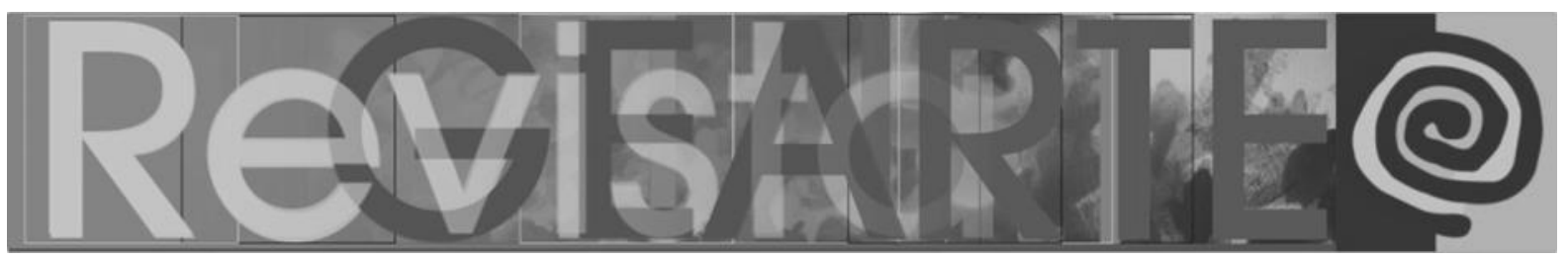

distintas, os quais evidenciam a produção de significados no ato de imprimir marcas ou de desenhar; e cujas imagens nos permitem pensar a prática e as relações educativas implicadas nessas oportunidades pelas quais as crianças constroem a experiência de desenhar - do grafismo ao desenho - na educação infantil.

\section{Contexto de Grafismo como possibilidade à constituição da experiência de desenhar}

A prática denominada Contexto de Grafismo, constitui uma proposição didática apresentada a crianças pequenas, se conforma por aspectos estruturantes: a configuração de elementos para a utilização de riscantes em suportes evidenciados, à exploração e experimentação dessas materialidades pelas crianças; e a vivência da impressão de marcas, à apreciação compartilhada e interpretação de suas produções como referências iniciais na constituição da experiência de desenhar. Parte das condições observadas de crianças pequenas, entre 20 e 24 meses, cujas demandas de movimentação se manifestam pela premência corporal como modo peculiar de apropriação dos elementos do ambiente, sendo constatado de fundamental importância, prover recursos mediadores à configuração das materialidades a fim de favorecê-las em suas interações.

A fim de compreender os aspectos destacados acerca da situação educativa denominada Contexto de Grafismo, apresentamos uma análise dos momentos da referida situação como exercício reflexivo em busca de uma estrutura pertinente ao paradigma da prática educativa, enunciado pelas Diretrizes Curriculares Nacionais para a Educação Infantil (DCNEI) - a criança como foco e as relações que ela estabelece em suas interações como o constructo da sua experiência -, e que contribui para pensar a constituição dos campos de experiência da criança pequena.

A situação educativa em questão envolve três crianças - pares recorrentes em situações diversas do cotidiano -, em uma proposta do Contexto de Grafismo que

com múltiplas linguagens e as provocam a interagir e estabelecer relações significativas ao seu processo educativo. 


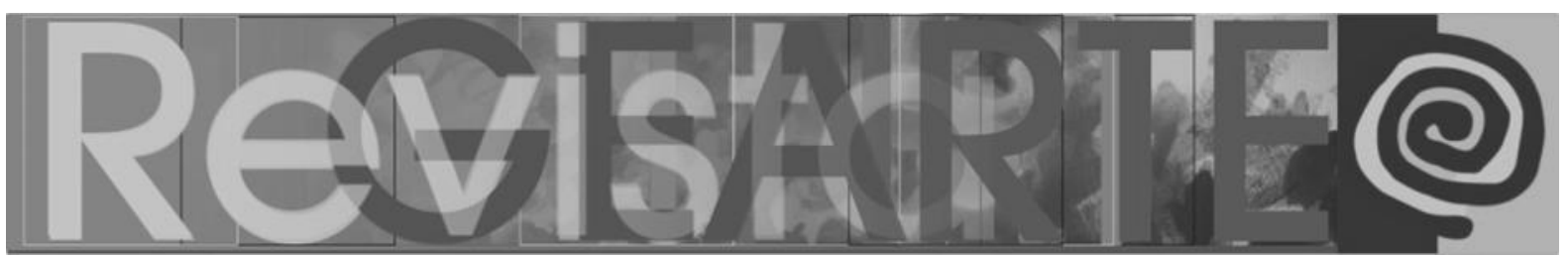

apresenta giz de cera e papel branco fixado em um tablado, elemento de apoio que permite a elas se debruçarem sobre o suporte e realizar ações em sinergia com a sua movimentação.

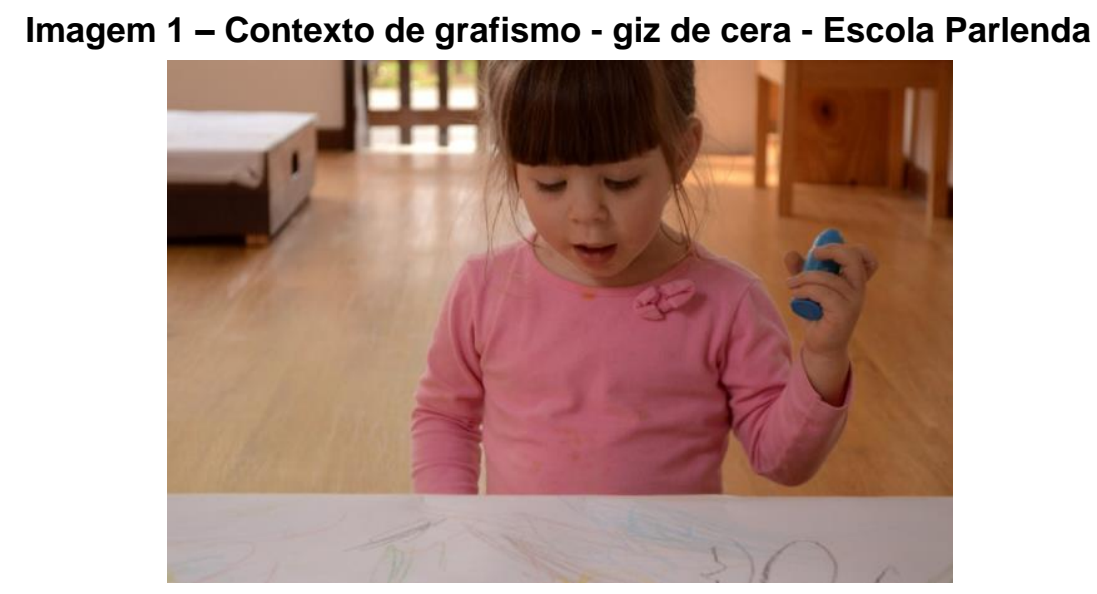

Fonte: Acervo das Autoras (2018).

Nesta primeira imagem (01) se evidencia uma expressão que remete ao assombro, o que sugere pensar na capacidade da criança de imprimir marcas em relação com o imaginário pela percepção do efeito criado, dada na extensão do gesto ou gerada na interação com a própria produção. E ainda, mediante a informação deste contexto de grafismo preparado para um pequeno grupo de crianças - três meninas que permaneceram grande parte do tempo próximas e atuando em um mesmo suporte, podemos também pensar que, além do assombro, esta criança da imagem (01) externaliza saberes na apreciação de sua produção pelo compartilhamento de significados com seus pares. Como testemunho (MERLEAU-PONTY, Apud, RICHTER, 2016), a palavra restitui o gesto em expressão, o que sugere dar visibilidade à marca, como presença criada que detém vida pela ação da criança. 

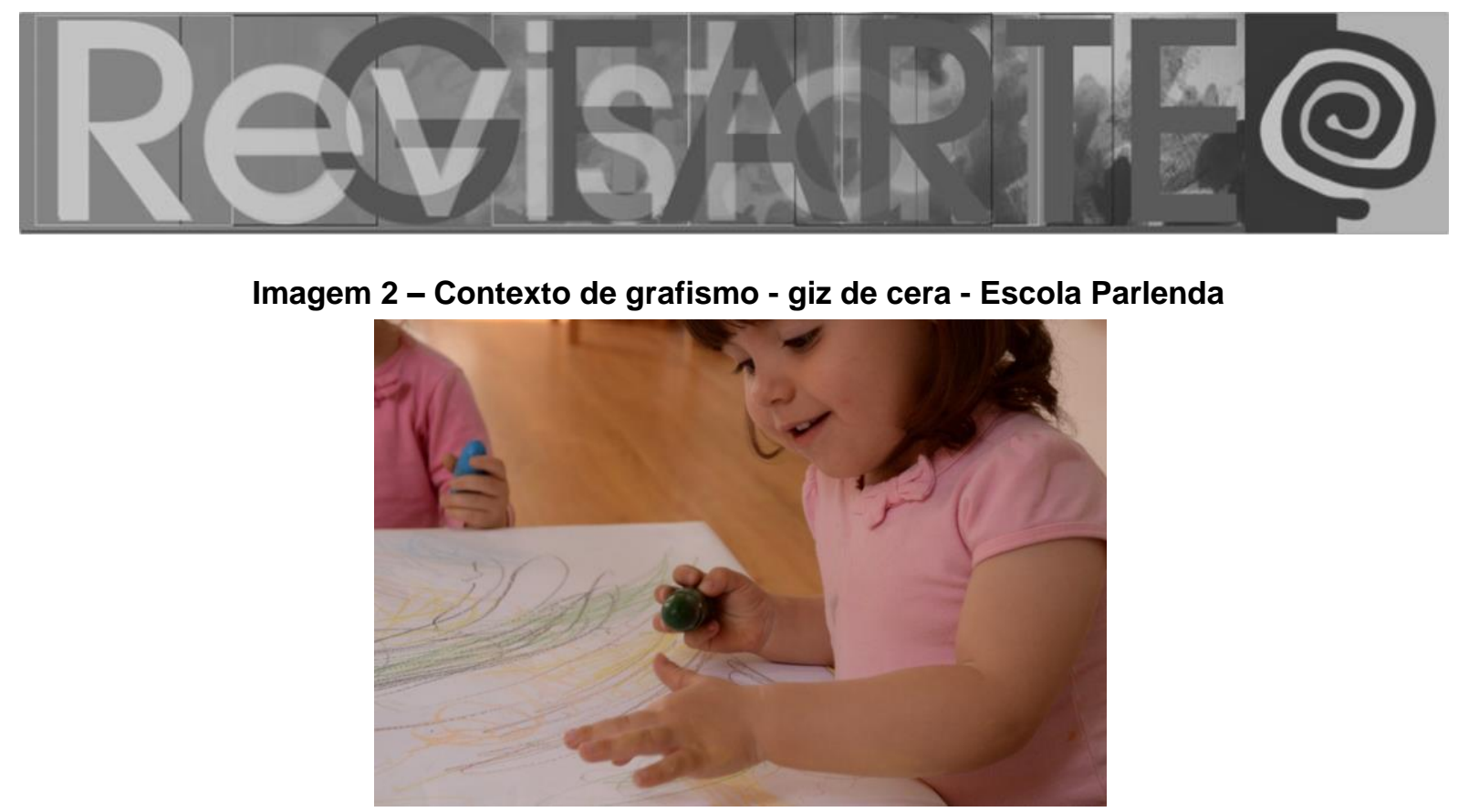

Fonte: Acervo das Autoras (2018).

Nesta direção, esta segunda imagem (02) comunica uma mensagem, o olhar e o gesto apontam para a produção gráfica traduzindo "aqui eu fiz". Sorriso e olhos revelam uma expressão da criança que insinua a satisfação diante da marca impressa, a ação realizada é propulsora de um pensamento que ora se nutre do imaginário e manifesta o verbo. Diante das interações provenientes da prática observada materialidades pertinentes em sua natureza, forma e composição; pares que compartilham saberes -, depreendemos que se expressar sobre o elemento impresso constitui característica intrínseca à ação de imprimir marcas. Enquanto atribuem significados aos traços, as crianças pequenas dão nome e lugar para algo produzido, vivido e revivido, revelando indícios dos sentidos implicado no ato de desenhar.

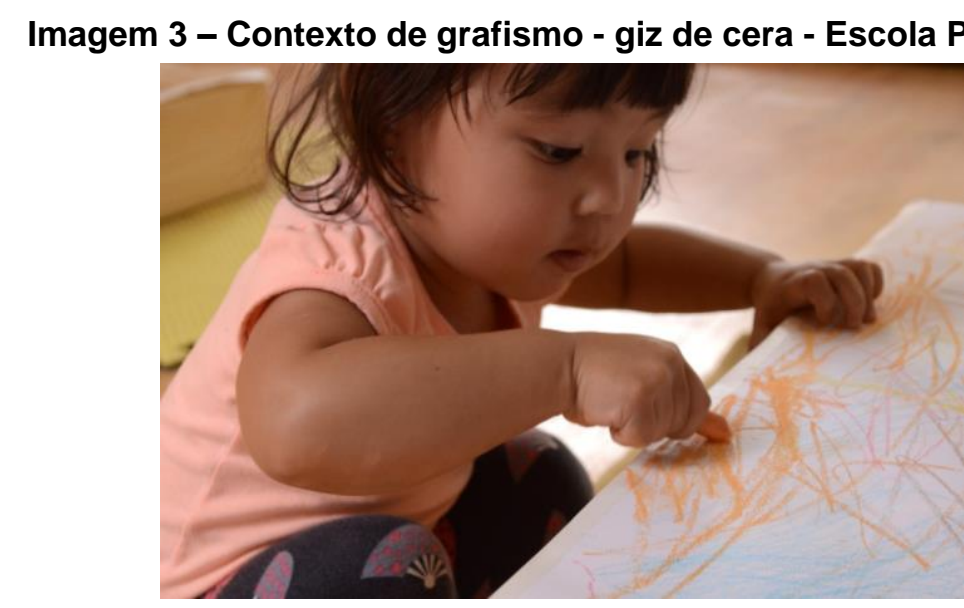

Fonte: Acervo das Autoras (2018). 


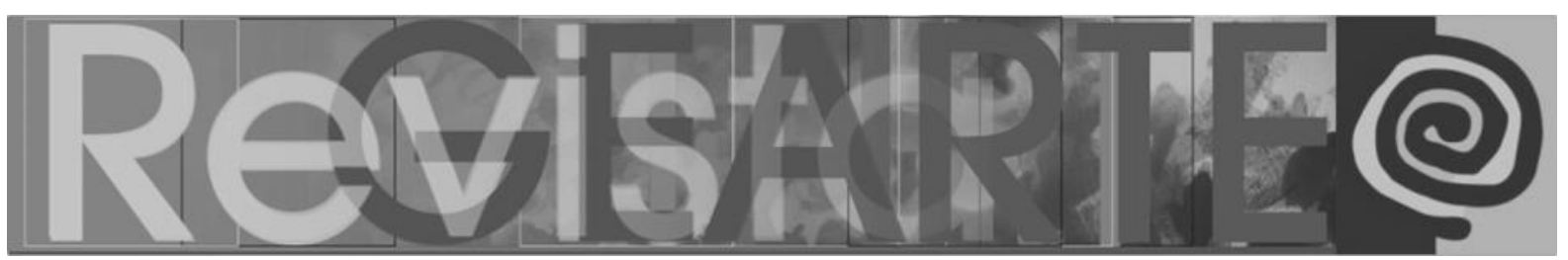

Nesta terceira imagem (03), percebemos o gesto que alicerça a ação sustentado por um corpo inteiro. A criança é corpo, gesto e movimento, como um sistema radial e integrado que se constitui por influências recíprocas, da mão direita que imprime força e produz o traço, do olhar que declara a intenção de deixar marcas, da postura de equilíbrio de um tronco inclinado, com pernas de cócoras e a mão esquerda apoiada no suporte-apoio. A autonomia de movimentação dessa criança revela o equilíbrio que a sustenta ao desenhar com o corpo inteiro para compor, sobrepor, repetir, modificar, expressar o imaginário. Atenta e imersa no aprimoramento de cada traço, a escuta dos pares dialoga com seu imaginário e surge um significado compartilhado: "O tubarão!". A concentração no gesto, a postura construída pelo equilíbrio do corpo, a intencionalidade representada pela incidência de rabiscos, remetem ao "fazer de novo" (BENJAMIN, 1986) como possibilidade à aquisição de um modo de imprimir marcas ou desenhar. Enquanto a significação do traçado revela nessa ação da criança, uma convergência do vivido emergindo como conteúdo da experiência, o que ela aciona mediante a necessidade de comunicar-se com o outro pelo que a afeta.

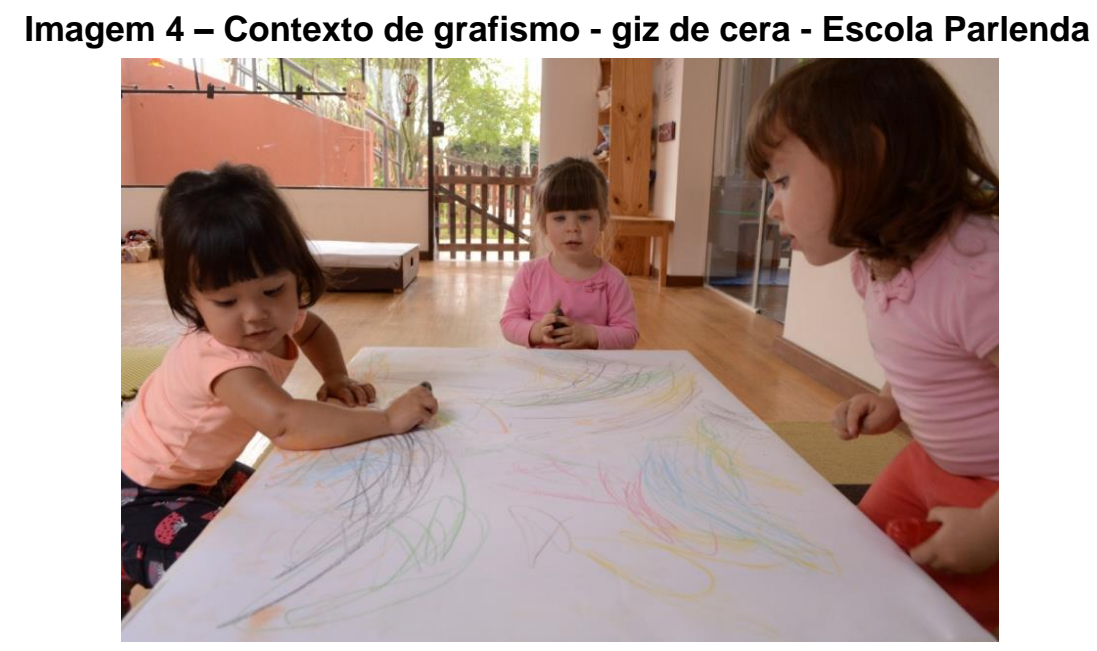

Fonte: Acervo das Autoras (2018).

Nesta última imagem (04), as três crianças observam a produção compartilhada, como apreciação e construção de sentidos à experiência de desenhar - produzir marcas e comunicar - evidenciando significados comuns "O tubarão!", "É o peixão", advindos da experiência coletiva, que abarca situações diversas pelas quais 


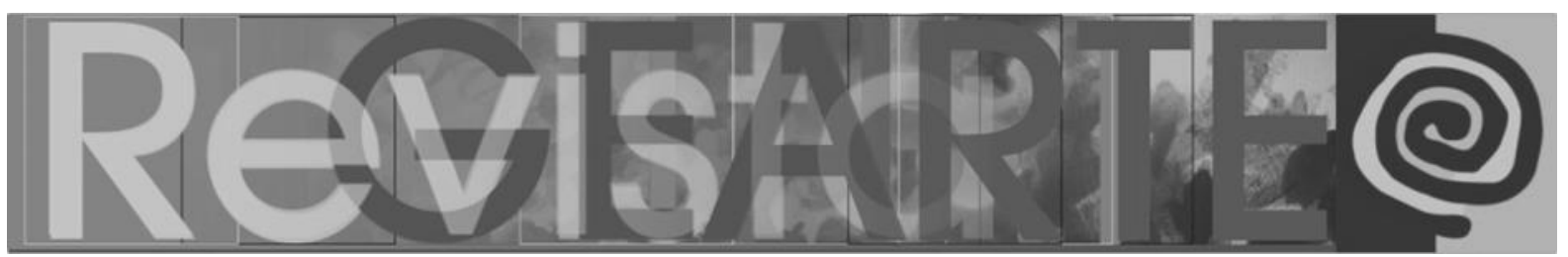

relacionam os enredos que compõem brincadeiras, leitura de histórias e jogos vivenciados pelo grupo de referência. O Contexto do Grafismo, se torna uma oportunidade que propicia à criança pequena expandir o imaginário pela complexificação das linguagens - do gesto à palavra, da ação de imprimir marcas ao ato de desenhar, da criação de um símbolo ao significado construído -, desde a criança consigo e em relação com seus pares, comunica, reitera e se modifica com a perspectiva do outro. A linguagem como fenômeno propriamente humano, restitui de sentido a ação produzida com intenção de expressar e comunicar algo a ser percebido por outros, o que a criança pequena pode apreender em sua condição de sujeito sociocultural, mediante as linguagens que tem oportunidade de vivenciar e desenvolver.

Acerca da prática Contexto de Grafismo com crianças pequenas, pensar a materialidade proposta - suporte, riscante, apoio - e a composição do grupo - número de crianças e sua relação cotidiana -, se torna relevante à reflexão sobre o papel do adulto de criar oportunidades que, convidam e provocam a criança a experimentar e construir relações, considerando sua potência e capacidades em desenvolvimento, mas, que também a respeitam em sua condição como sujeito que detém saberes e repertórios. Nessa perspectiva, as escolhas do adulto compõem o espaço-ambiente ${ }^{3}$ da sessão em foco - materialidade, pequeno grupo de crianças, adultos presentes como uma ambientação que favorece a interação das crianças com a materialidade e entre si, tal como as imagens revelam (Fotos 1, 2, 3 e 4), e declara a intencionalidade pedagógica do Contexto de Grafismo.

A percepção e compreensão do que as crianças realizam na oportunidade do Contexto de Grafismo, evidenciam seus saberes, repertórios e competências, mas também indiciam possibilidades a serem consideradas e contempladas em novas ambientações dessa proposta, como direito a aprendizagens que promovam suas

3 A ideia de espaço-ambiente consiste em considerar os aspectos físico-materiais - delimitação arquitetônica, elementos fixos e flexíveis, elementos efêmeros - e os sujeitos envolvidos - crianças e adultos - como constituintes de uma atmosfera que representa o concreto e o vivido no cotidiano da Educação Infantil (VIEIRA, 2016).

VIEIRA, Daniele Marques; PANDINI, Silvia. Práticas que convidam a olhar e a pensar relações 


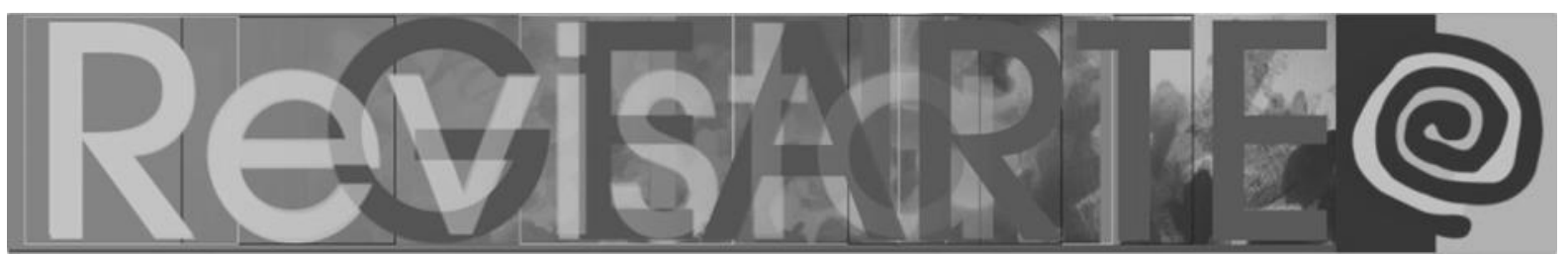

potencialidades - aprimorar habilidades de representação; comunicar relações implicadas no desenho; manifestar o vivido como acontecimento; visibilizar a subjetividade por múltiplas linguagens.

A seguir, apresentamos uma proposta denominada Contexto de Desenho de Observação ao Ar Livre, que utiliza elementos da natureza como materialidades para representação. Nesta prática se evidencia a inter-relação dos eixos Arte e Natureza ${ }^{4}$ e a maneira como eles se imbricam pelos conceitos de sazonalidade, metamorfose, efemeridade e permanência. Conceitos esses que se aplicam tanto às ações vinculadas ao ato de desenhar pela criança quanto à percepção do espaço natural, caracterizado pela atmosfera ao ar livre e seus elementos - árvores, galhos, céu, nuvens, insetos, pássaros, terra, entre outros. Dada a intencionalidade de demarcar o elemento de continuidade ${ }^{5}$, como riscante de origem orgânica, se elegeu o carvão, por materializar as tantas metamorfoses que a planta sofreu, e ainda, em contraponto à sua efemeridade ou permanência, por deixar marcas quando tomado pelas mãos das crianças.

\section{Contexto de Desenho de Observação ao Ar Livre: as árvores do quintal}

A prática denominada Contexto de Desenho de Observação ao Ar Livre desenho a carvão, intenciona apresentar às crianças o convite para desenhar, produzindo marcas gráficas ao representarem um espaço vivenciado no quintal, bem como apreciar e interpretar de forma compartilhada as próprias produções e as dos colegas. O convite foi declarado pela proposta de desenhar ao ar livre na interação com a natureza como elemento de observação, sendo possibilitado às crianças se

4 Destaca-se que na instituição em foco, a proposta pedagógica se estrutura pelos eixos Interações, Brincadeira, Natureza e Arte.

5 A ideia de elemento de continuidade consiste no propósito de apresentar o mesmo elemento em diferentes contextos a fim de provocar a criança na ampliação de sua perspectiva, em relação às possibilidades do desenho. Apesar de as demais propostas realizadas não serem abordadas nesse texto, destacamos o Contexto de Desenho na Mesa de Luz - elemento de continuidade: carvão. 


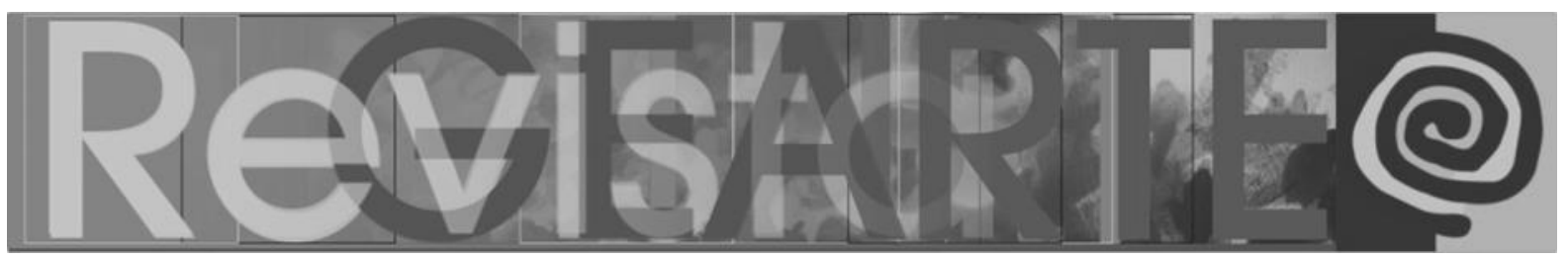

deslocarem passeando por entre os cavaletes e as árvores, o que Ihes permitiu observar os elementos desse ambiente sob diferentes pontos de vista.

Para a criança, ter a chance de desenhar ao ar livre é desfrutar da oportunidade de tomar os elementos em perspectiva: ir até o objeto, tocá-lo, ir novamente até o cavalete, fazer uso das mãos tanto para segurar os riscantes quanto para tocar as árvores e os papeis que recebem os traços. Esse vai e vem pelo espaço ao ar livre permite viver e reviver a sensação do que se quer representar. Aos 3 anos, essa fluidez dos movimentos do próprio corpo permite ao gesto aproximar-se do imaginário, permite materializar o que os "olhos pensam em não ver", como sugere Derrida (2002).

A situação educativa em questão envolve um grupo de 6 crianças de 3 anos, em um espaço da escola ao ar livre, preparado com cavaletes recobertos com cartolina branca. A presença dos cavaletes é reconhecida por elas como local destinado às suas investigações e registros gráficos por meio de desenhos. $O$ riscante disponibilizado foi o carvão industrializado, em forma cilíndrica. A proposta que convida as crianças a realizarem a observação ao ar livre para representar por meio do desenho suas percepções e relações acerca do elemento em foco - árvores -, se ancora na própria experiência da criança com a natureza, e prevê como possibilidade acionar a sua sensibilidade acerca desse contexto.

Bachelard (2008) nos ensina que "O minúsculo e o imenso são consonantes". A natureza nos traz a perspectiva do imenso. E também do minúsculo. Aos olhos das crianças, e dos observadores pacientes, o microcosmo tem amplitude digna de imensidão, assim, se torna fundamental para uma produção profícua e significativa, imiscuir-se de natureza. 


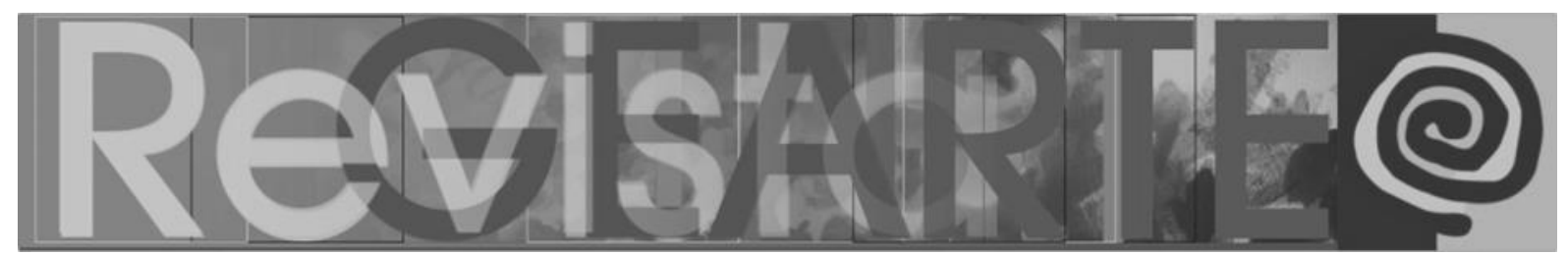

Imagem 5 - Contexto de desenho de observação ao ar livre - desenho a carvão - Escola Parlenda

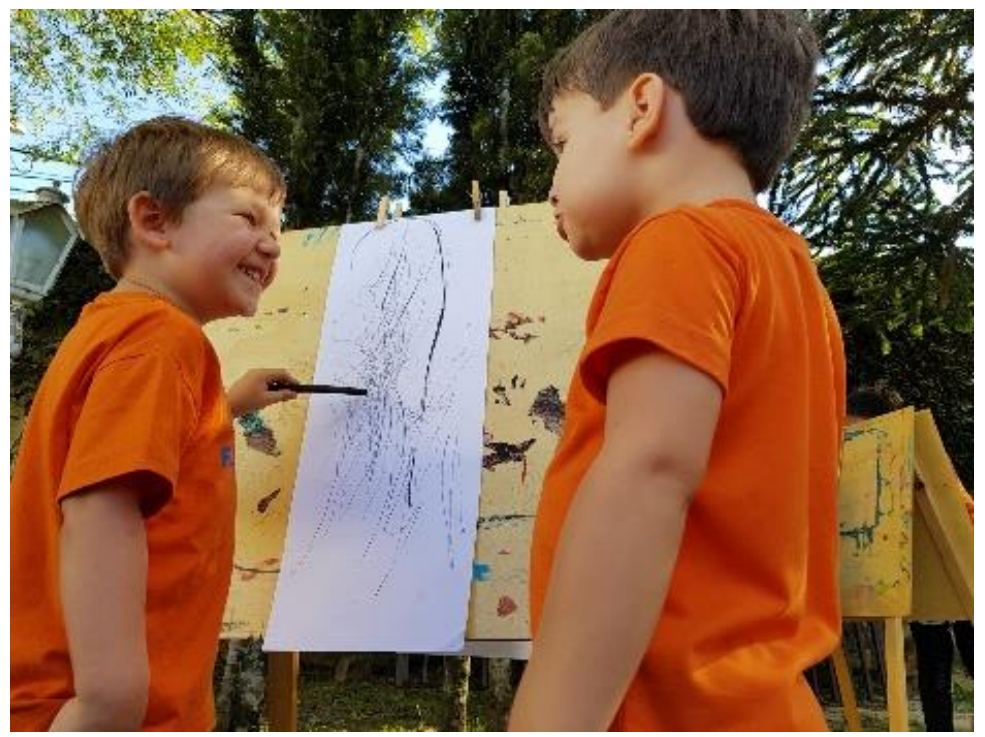

Fonte: Acervo das Autoras (2018).

Nesta imagem (05) as crianças estão em pé diante do papel em que irão desenhar, de modo que convocam todo o corpo a exercer um amplo, harmonioso, brusco ou leve e lento movimento. Do aspecto capturado pela imagem (Foto 5), se depreende que o ato de dialogar e compartilhar impressões sobre o observado ao ar livre é parte da ação de desenhar e das iniciativas das crianças para tornar o mundo inteligível. Mais confiantes e conscientes das potencialidades de seus corpos e movimentos, vemos as crianças atuando de formas mais complexas em seus deslocamentos, na relações que estabelecem entre os elementos e na execução de seus traços. 


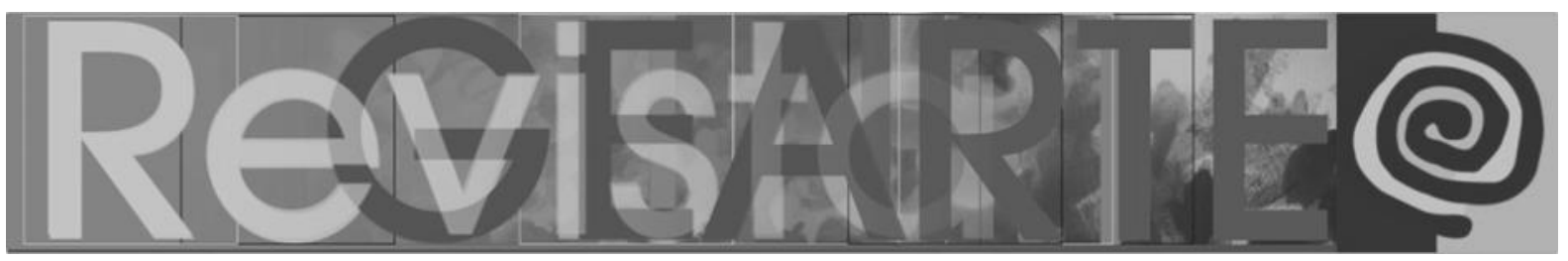

Imagem 6 (composição) - Contexto de desenho de observação ao ar livre - desenho a carvão Escola Parlenda

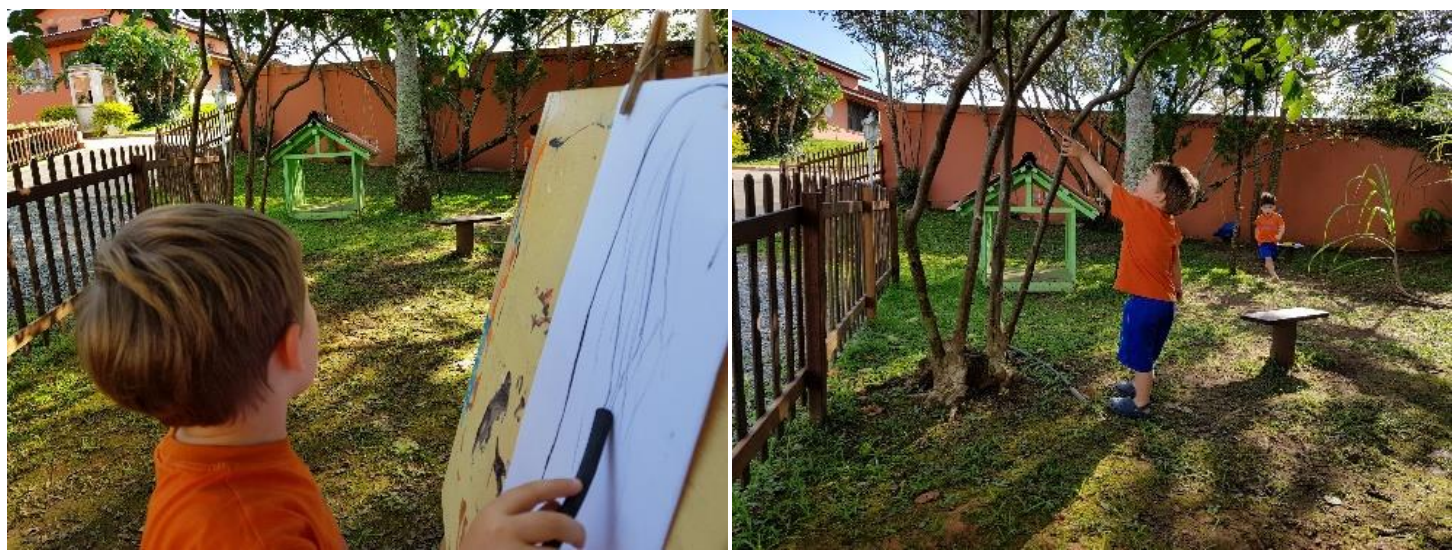

Fonte: Acervo das Autoras (2018).

Nessa composição de imagens (06), se revela uma corporeidade própria ao desenho de observação ao ar livre, cujo corpo infantil manifesta o gesto como extensão do pensamento. Olhar e mover-se para pôr à prova o que os olhos parecem não ver. Aproximar-se e afastar-se na tentativa de depreender os componentes e resolver como operar a transição da tridimensionalidade para a representação bidimensional.

Imagem 7 (composição) - Contexto de desenho de observação ao ar livre - desenho a carvão Escola Parlenda

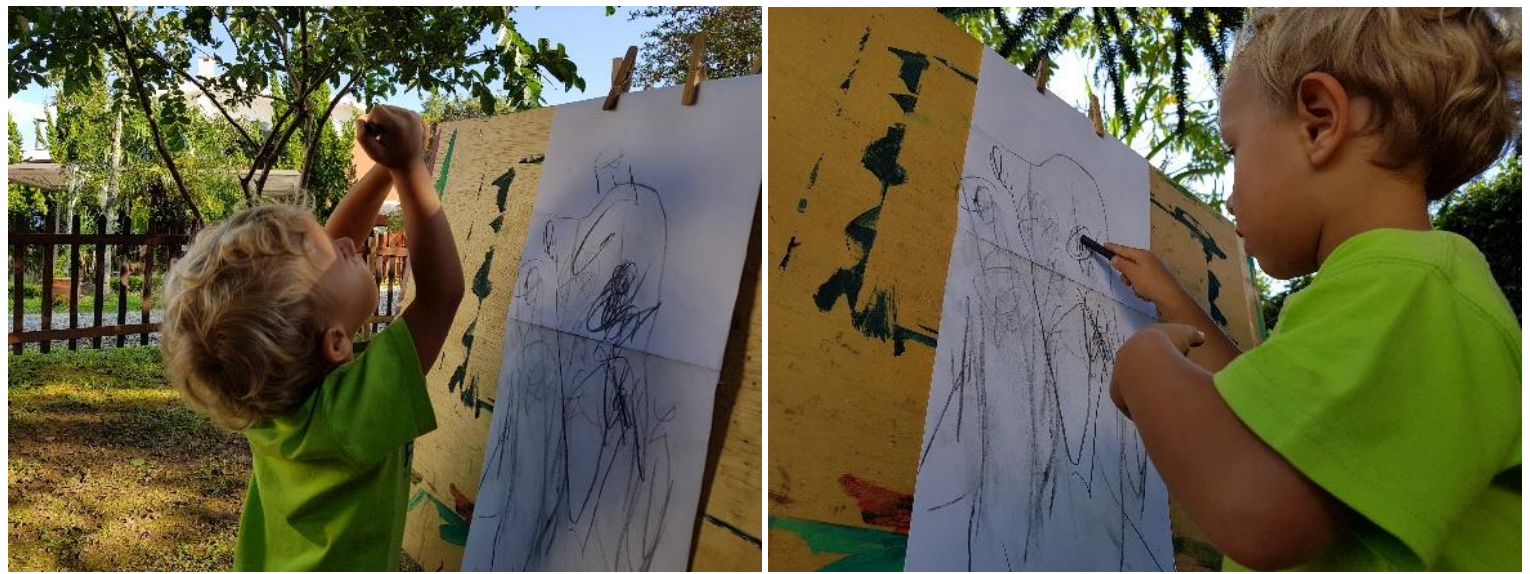

Fonte: Acervo das Autoras (2018).

Nessa outra composição de imagens (07), vislumbramos como o desenho se constitui pela extensão do vivido. Desde perceber a grandiosidade e a peculiaridade do elemento de observação - árvore - pelo gesto que aproxima, o olhar que alcança 


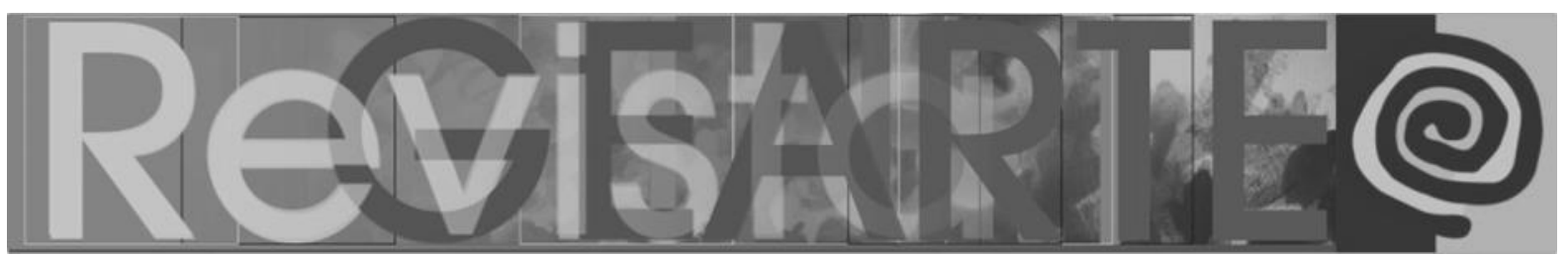

com as mãos, o traço que traduz o visto, enquanto o não visto nutre a interpretação do sujeito que representa. A marca produzida com o carvão, provoca a criança em sua sensorialidade, que na percepção do efêmero, vê nascer a novidade e aprecia seu feito. A surpresa convoca as demais crianças a lerem mútua e simultaneamente os gestos corporificados em traços e se manifesta uma apreciação compartilhada.

Notamos nessas composições de imagens (06 e 07) gestos coordenados de corpos que se especializam na observação e dão à mão o não visto. A mão se estende para capturar o que toca, seja a árvore sejam os próprios traços das crianças. Observar, tocar, olhar de perto, tocar de novo para dimensionar o objeto são algumas das ações presentes no Contexto de Desenho de Observação ao Ar Livre, que o caracterizam e o delimitam como proposta pertinente à faixa etária. Ao contemplar essas ações como componentes ativos da proposta, o adulto conforma o contexto dando vazão aos anseios infantis de significar o mundo, o que consiste didaticamente como diálogo entre corpo, gesto, movimento e a capacidade de representar o visto e o não visto pelo ato de desenhar.

O gesto desenha, procura lugar, num aproxima-afasta como uma dança da criança pelo espaço. Esse bailar de simultaneidades também se dá entre a apreciação, a exploração e a execução do desenho. Não é possível dizer que tais ações se sucedam, porque estão em sincronicidade. Para a criança, pesquisar, deterse, registrar, apreciar a própria produção ou a produção alheia ou contemplar a natureza são elementos dados e incorporados como parte do acontecimento que não cessa de acontecer. Como "jogo de traçar linhas, riscar e rabiscar, só alcança êxito quando permite a quem o faz seguir brincando" (RICHTER, 2016, p.200), projetando, se deslocando, imaginando e tecendo a imprevisibilidade.

Desenhar se conforma como uma ação de cognição sobre o mundo, um acontecimento que não finda, é uma ode ao efêmero. Ao desenhar, pelo gesto, a criança congrega esse poder de capturar o efêmero. Contudo, uma vez nascida a marca, ela é acontecimento que não cessa de acontecer no mundo. A marca gráfica 


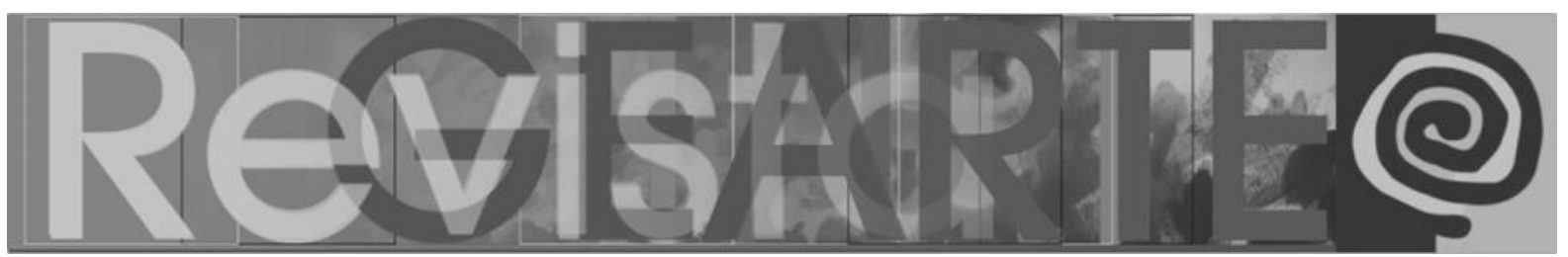

nascida não se finda, uma vez que pode ser vista, lida e apreciada tantas vezes quanto se queira. E nesse afã de tornar o mundo inteligível desenhando-o, muitas ações se entrelaçam, tais como vocalizar e narrar o que surge, gestualizar e mover o braço, deixar uma marca gráfica e contemplá-la.

Imagem 8 (composição) - Contexto de desenho de observação ao ar livre - desenho a carvão -
Escola Parlenda

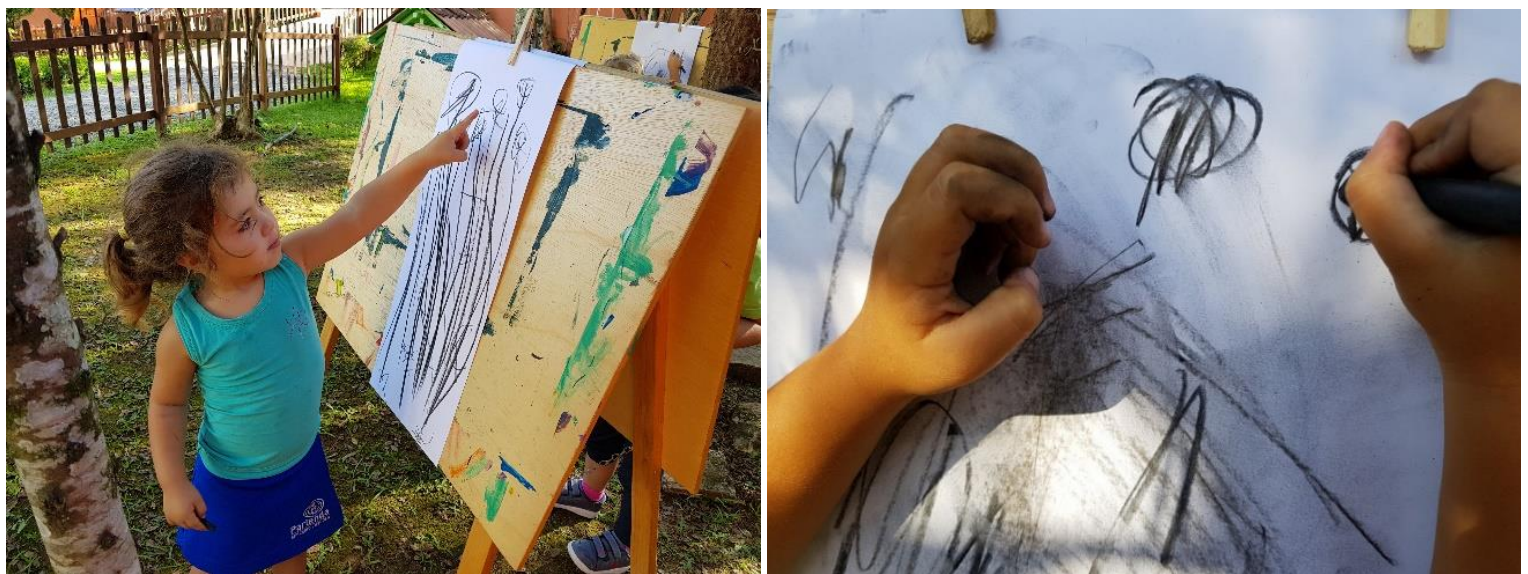

Fonte: Acervo das Autoras (2018).

Nas imagens dessa composição (08), as mãos são instrumentos à constituição de hábitos construídos pelos pequenos dedos da criança, do domínio do riscante, do reconhecimento da marca na extensão do gesto, do poder das mãos sobre a materialidade em conter o imaginário que urge escapulir como realidade. Em seus pequenos olhos cabe um universo infinito e elas querem descobri-lo e simbolizá-lo. Interpretar e reconhecer o mundo, interpretar-se e reconhecer-se no mundo, inerente ao cotidiano das crianças, se materializa no ato de desenhar como significados intrínsecos a ele.

Ao analisarmos a proposta do Contexto de Observação ao Ar Livre - desenho com carvão, situação educativa em foco, enleva como elementos didáticos: a possibilidade das crianças explorarem o contexto pela interação com a materialidade, os elementos de observação e os pares; e a intenção declarada que convoca as crianças a executarem ações que melhor satisfazem suas gramáticas e fantasias. 


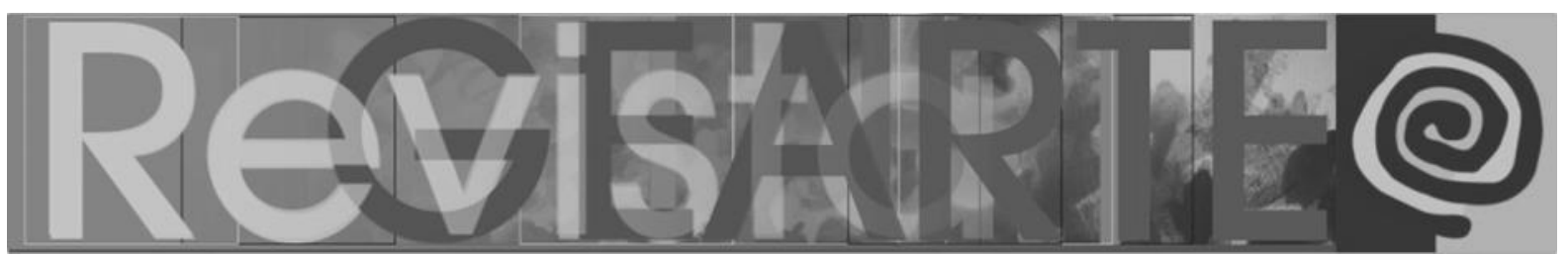

Por fim, podemos constatar que, ao atuarem com o carvão como riscante, as crianças puderam descobrir as tantas virtudes desse elemento orgânico, a partir de sua característica efêmera. O carvão transmuta-se. O carvão já foi madeira que, queimada, sapecou nosso pinhão. O carvão é origem do grafite. O carvão mancha a pele e o papel. O carvão se desfaz. O carvão esfumaça. O desenho a carvão, executado pelas crianças, é um pergaminho. Pouco a pouco, muitas versões do desenho se sobrepõem. E as narrativas gestual e oral se esvanecem para, em seguida, cederem lugar a mais uma narrativa visual. Nas mãos das crianças ele fornece a maciez e porosidade necessária para que o gesto executado pelo corpo dance sobre a superfície. Dancemos todos nós pelos sinais e imagens das crianças, que com suas miradas povoam o mundo com novas sutilezas.

\section{Considerações para pensar novas possibilidades}

Implicadas pela filosofia e pela estética, em diálogo com a didática, nos propusemos a pensar a prática por uma premissa que concerne propiciar às crianças vivências pelas quais possam construir sentido à sua experiência educativa, desde si, que se desloca da centralidade do adulto e se sustenta por intencionalidades previstas por oportunidades que convidam e convocam as crianças a realizarem interações profícuas, implicadas pelo que as mobilizam.

Nessa perspectiva, da criança e das relações que ela estabelece enquanto constructo da sua experiência, se assentam como conteúdos da prática educativa a exploração, a experimentação, a apropriação, a ampliação e a complexificação do conhecimento sobre o mundo material e das capacidades que compõem sua potência. Uma vez que se entenda o contexto de vida da criança pela complexidade que é, dadas as suas referências socioculturais, seu lugar historicamente construído na sociedade, as relações que a constituem e os percursos demarcados pelo que a afeta, move e provoca a conhecer, se apropriar e dominar. Assim, podemos pensar que as propostas do Contexto de Grafismo e do Contexto de Desenho de Observação ao Ar Livre, constituem oportunidades para apresentar referentes da cultura plástica e para 


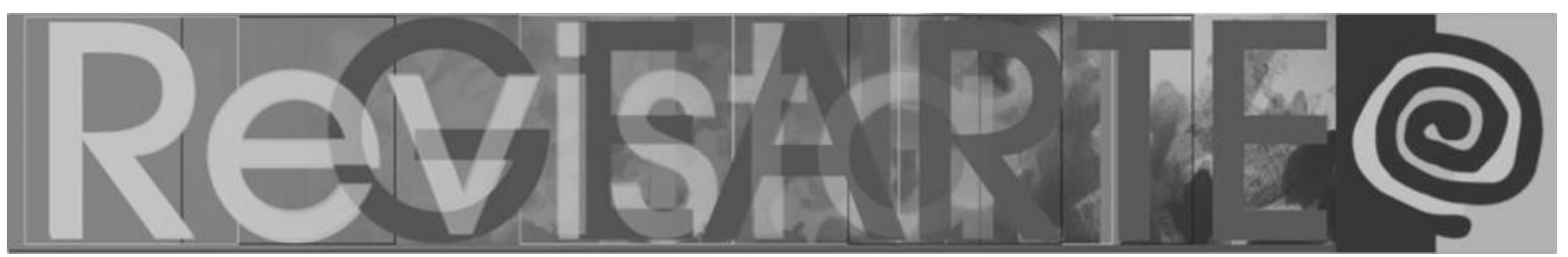

propiciar a emersão de conteúdos subjetivos representados pelo imaginário infantil, configurando uma inter-relação de Campos de Experiências no ato de desenhar, evidenciada pelas ações de produzir marcas e comunicar, bem como, observar, tocar, dimensionar e representar.

Desenhar seria então, um voo entre o imaginário e o poder de criar, a partir de $\mathrm{si}$, do gesto e do corpo em movimento, em torno de possibilidades a construir novas versões do mundo, do que pensar em não ver nutre o traço, marca, significa o vivido pelo pensamento que toma uma forma, referência de algo que se produziu e se constitui em experiência.

\section{Referências}

BACHELARD, Gaston. A poética do espaço. São Paulo: Martins Fontes, 2008.

BACHELARD, Gaston. A terra e os devaneios da vontade: ensaio sobre a imaginação das forças. São Paulo: Editora WMF Martins Fontes, 2013.

BARTHES, Roland. A câmara clara. Arte e Comunicação, Lisboa: ed. 70,1980.

BENJAMIN, Walter. Magia e técnica, arte e política. 2.ed. São Paulo: Brasiliense, 1986.

BRASIL. Diretrizes Curriculares, Nacionais para a Educação Infantil. Conselho Nacional de Educação. Câmara de Educação Básica. Resolução CNE/CEB n. 5, 17 de dezembro de 2009.

DERRIDA, Jacques. Pensar em não ver: escritos sobre as artes do visível (1979-2004). Editora UFSC, 2012, p. 65 a 89.

OLIVEIRA, Zilma M. R. de. Campos de Experiências: efetivando direitos e aprendizagens na educação infantil. São Paulo: Fundação Santillana, 2018.

RICHTER, Sandra. Traçar, riscar e rabiscar: experiência de desenhar na educação infantil. In: ACHE, Viviane; GALLINA, Simone F. da S.; WESCHENFELDER, Noeli (Orgs.). Pedagogias das infâncias, crianças e docências na educação infantil. Santa Maria: UFSM; Brasília: MEC, 2016.

VIEIRA, Daniele M. Imagens da experiência educativa de professores da educação infantil no espaçoambiente do Proinfância. 2016. 228 f. Tese (Doutorado em Educação) - Setor de Educação, Universidade Federal do Paraná, Curitiba, 2016.

\section{Daniele Marques Vieira}

Possui graduação em Pedagogia pela Universidade Federal do Paraná (1994), Mestrado em História pela Universidade Federal do Paraná (1998) e Doutorado em Educação pela Universidade Federal do Paraná (2016), tendo realizado doutorado sanduíche na Universidad de Barcelona, Espanha, sob a supervisão do Prof. Dr. José Contreras Domingo. Tem experiência na área de Educação Infantil, tendo sido professora e coordenadora pedagógica nesta etapa da Educação Básica e docente do Ensino Superior em cursos de Pedagogia. Integrante do Núcleo de Estudos e Pesquisas sobre Infância e Educação Infantil (NEPIE/UFPR) e do Grupo de Trabalho de Educação Infantil (GTEI) da UFPR, que integra o Fórum de Educação Infantil do Paraná - FEIPAR, que compõe o Movimento Interfóruns de

VIEIRA, Daniele Marques; PANDINI, Silvia. Práticas que convidam a olhar e a pensar relações 562

e sentidos construídos pela criança em sua experiência de desenhar na educação infantil.

Revista GEARTE, Porto Alegre, v. 6, n. 3, p. 545-563, set./dez. 2019.

Disponível em: http://seer.ufrgs.br/gearte 


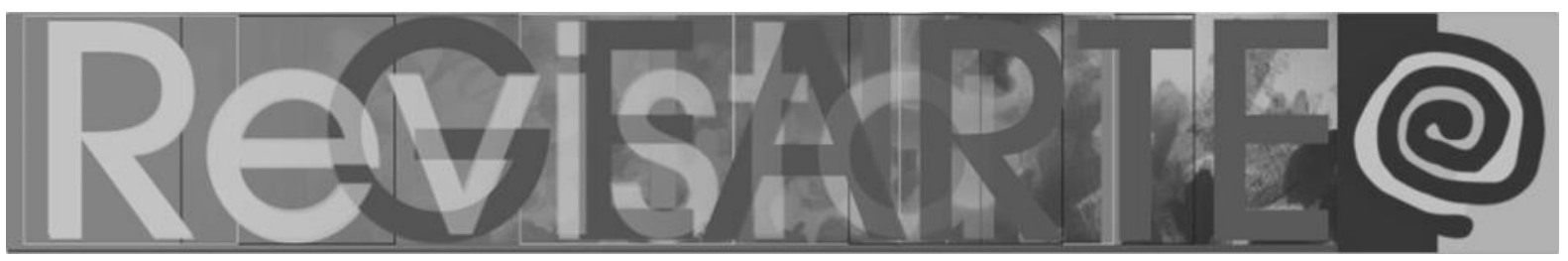

Educação Infantil do Brasil - MIEIB. Exerceu também a docência no Curso Superior de Tecnologia em Fotografia da UTP, nas disciplinas de História da Imagem e da Fotografia e Fotografia Ambiental, sendo a fotografia a linguagem que vem utilizando para compor propostas metodológicas de estudo na área educacional, bem como sua forma de representação artística. Estuda a experiência pela investigação das narrativas visuais e da memória narrativa, com foco nas relações educativas que envolvem estudos com bebês ( 0 a 3 anos de idade). Atualmente, atua como consultora de educação infantil.

ORCID: https://orcid.org/0000-0001-6866-7053

E-mail: danielemarquesvieira@gmail.com

Currículo: http://lattes.cnpq.br/5548274661198509

\section{Silvia Pandini}

Possui graduação em Pedagogia (2003) e mestrado em Educação (2006) pela Universidade Federal do Paraná. Tem experiência na área de Educação e já atuou nas áreas: formação continuada de professores, revisão de material didático, assessoria para produção de projetos pedagógicos e matrizes curriculares, coordenação pedagógica escolar, docência em educação infantil, ensino básico e superior, elaboração de webconferências para o ensino à distância, organização de congressos e seminários educacionais nas redes pública e privada. Atualmente tem se dedicado à pesquisa do papel do Atelierista na escola de Educação Infantil e às investigações das linguagens infantis.

E-mail: pandinisilvia@gmail.com

Currículo: http://lattes.cnpq.br/5189549405001157

Recebido em 30 de abril de 2019 Aceito em 31 de agosto de 2019 